\title{
Pengaruh Pemanfaatan Teknologi Informasi Dan Sumber Daya Manusia Terhadap Ketepatwaktuan Pelaporan Keuangan Pemerintah Daerah
}

\author{
Shenyta Denofi Kurniawati ${ }^{1}$, Hustianto Sudarwadi ${ }^{2}$, Mona P. Mokodompit ${ }^{3}$ \\ 1, Alumni Jurusan Akuntansi, Universitas Papua \\ ${ }^{2,3}$ Dosen Jurusan Akuntansi, Universitas Papua
}

Received: Maret 2019; Accepted: Juni 2019; Published: September 2019

\begin{abstract}
Abstrak
Penelitian ini bertujuan untuk mengetahui: (1) Pengaruh pemanfaatan teknologi informasi terhadap ketepatwaktuan pelaporan keuangan pemerintah daerah, (2) sumber daya manusia terhadap ketepatwaktuan pelaporan keuangan pemerintah daerah. Jenis penelitian ini adalah penelitian kuantitatif. Populasi dalam penelitian ini adalah jumlah pegawai Organisasi Perangkat Daerah (OPD) yang ada di Kabupaten Manokwari yang berjumlah 1.925 yang terbagi dalam 27 OPD. Teknik pengambilan sampelnya menggunakan metode random sampling dan diperoleh sampel sebanyak 331 dengan menggunakan rumus slovin. Jenis data penelitian ini adalah data primer. Penelitian ini menggunakan teknik pengambilan data dengan menyebarkan kuesioner kepada responden, sedangkan sumber data primer dalam penelitian ini diperoleh dari jawaban atas kuesioner yang dibagikan kepada responden yaitu Pegawai di OPD. Hasil penelitian menyimpulkan bahwa pemanfaatan teknologi informasi dan sumber daya manusia berpengaruh signifikan positif terhadap ketepatwaktuan pelaporan keuangan pemerintah daerah.
\end{abstract}

Kata kunci: pelaporan keuangan daerah, pemanfaatan teknologi informasi, sumber daya manusia

\begin{abstract}
The study aims to determinen: (1) the influence of the use of information technology on the timeliness of local government financial reporting, (2) human resources on the timeliness of local government financial reporting. This type of research is quantitative research. The population in this study is the number of staff of regional (OPD) in Manokwari regency totaling 1.925 which are devided into 27 OPD. The sampling technique wed 331 random sampling and individuals using the slovin formula. This type of research data is primary data, this study use data collection techniques by distributing questionnaires to respondent, while the primary data source in this study is obtained from respondents' answer to the questionnaires distributed to respondents' namely employes $O P D$. The result of the study conclude that: the use of information technology and human resources has a significant positive effect on the timeliness of local government financial reporting.
\end{abstract}

Keywords: local government financial reporting, the use of information technology, human resources

How to Cite: Kurniawati, S. D., Sudarwadi, H., Mokodompit, M. P. (2019). Pengaruh Pemanfaatan Teknologi Informasi dan Sumber Daya Manusia Terhadap Ketepatwaktuan Pelaporan Keuangan Pemerintah Daerah. JFRES: Journal of Fiscal and Regional Economy Studies, 2 (2), 67 - 75. 


\section{PENDAHULUAN}

Perkembangan sektor publik di Indonesia saat ini ditandai dengan menguatnya tuntutan akan akuntabilitas atas lembaga-lembaga publik, baik di pusat maupun daerah (Mardiasmo, 2002).

Bentuk pertanggungjawaban dalam penyelenggaraan pemerintah diatur dengan Undang-Undang No. 17 Tahun 2003 tentang Keuangan Negara dan UU No. 32 Tahun 2004 tentang Pemerintah Daerah, dimana pemerintah berupaya secara konkrit untuk mewujudkan transparasi dan akuntabilitas pengelolaan keuangan pemerintah baik pemerintah di pusat maupun di daerah adalah dengan menyampaikan laporan pertanggungjawaban berupa laporan keuangan.

Peraturan Pemerintah No. 71 tahun 2010 menjelaskan laporan keuangan merupakan laporan yang terstruktur mengenai posisi keuangan dan transaksi-transaksi yang dilakukan oleh suatu entitas pelaporan. Laporan keuangan pemerintah baik pusat maupun daerah merupakan representasi posisi keuangan dari transaksi-transaksi yang dilakukan oleh pemerintah. Selain dapat memberikan informasi yang digunakan sebagai dasar penyusunan anggaran pada periode berikutnya, laporan keuangan pemerintah daerah juga digunakan sebagai penilaian prestasi kerja pemerintah serta sebagai alat untuk memotivasi.

Adapun karakteristik kualitatif laporan keuangan pemerintah yang merupakan prasyarat normatif sebagaimana disebutkan dalam Rerangka Konseptual Akuntansi Pemerintah, dalam PP Nomor 71 Tahun 2010 antara lain: (1) relevan, (2) andal, (3) dapat dibandingkan, (4) dapat dipahami. Apabila informasi yang terdapat didalam Laporan Pemerintah daerah memenuhi kriteria.

Ketepatwaktuan adalah batasan penting pada publikasi laporan keuangan. Akumulasi, peringkasan, dan penyajian selanjutnya informasi akuntansi harus dilakukan secepat mungkin untuk menjamin tersedia informasi ditangan pemakai atau pengguna. Ketepatwaktuan menunjukan bahwa laporan keuangan harus disajikan pada kurun waktu yang teratur untuk memperlihatkan perubahan keadaan perusahaan yang pada gilirannya mungkin akan mempengaruhi prediksi dan keputusan pemakai. Apabila informasi tidak disampaikan dengan tepat waktu akan menyebabkan informasi tersebut kehilangan nilai dalam mempengaruhi kualitas keputusan. Informasi tepat waktu juga akan mendukung manajer menghadapi ketidakpastian yang terjadi dalam lingkungan kerja (Respati, 2001).

Hal pertama yang mungkin mempengaruhi ketepatwaktuan pelaporan keuangan pemerintah adalah Pemanfaatan Teknologi Informasi. Pemanfaatan teknologi informasi oleh Pemerintah Daerah dan OPD diatur dalam PP No. 56 tahun 2005 tentang Sistem Informasi Keuangan Daerah. Menurut Hartono (1995), informasi yang tepat waktu merupakan bagian dari nilai informasi yang dapat dicapai dengan peran komponen teknologi, informasi merupakan produk dari sistem teknologi informasi. Teknologi informasi berperan dalam menyediakan informasi yang bermanfaat bagi para pengambil keputusan di dalam organisasi termasuk dalam hal proses pelaporan sehingga mendukung proses pengambilan keputusan dengan lebih efektif. Suatu teknologi informasi terdiri dari: perangkat keras, perangkat lunak, manajemen data, dan jaringan (Widjajanto, 2001).

Hal kedua yang mungkin mempengaruhi dari ketepatwaktuan pelaporan keuangan pemerintah daerah adalah pengawasan keuangan daerah. Pengawasan adalah suatu upaya yang sistematik untuk menetapkan kinerja standar pada perencanaan untuk merancang sistem umpan balik informasi, untuk membandingkan kinerja aktual dengan standar yang telah ditentukan, untuk menetapkan apakah telah terjadi suatu penyimpangan, serta untuk mengambil tindakan perbaikan yang diperlukan untuk menjamin bahwa sumber data organisasi atau pemerintahan telah digunakan seefektif dan seefesien mungkin guna mencapai tujuan organisasi atau pemerintah. Pengawasan perlu dilakukan untuk mengetahui apakah perencanaan yang telah disusun dapat berjalan secara efesien, efektif, dan ekonomis (Arfianti, 2011).

Penelitian mengenai ketepatwaktuan pelaporan keuangan telah dilakukan oleh beberapa peneliti, Trisaputra (2013) meneliti di SKPD Provinsi Sumatra Barat. Peneliti tersebut menemukan pemanfaatan teknologi informasi 
dan pengawasan keuangan daerah berpengaruh signifikan positif terhadap ketepatwaktuan pelaporan keuangan. Sedangkan penelitian yang dilakukan oleh Chandra (2016) menemukan pemanfaatan teknologi informasi berpengaruh terhadap ketepatwaktuan pelaporan keuangan di Kabupaten Minahasa Tenggara. Hasil penelitian menunjukan pemanfaatan teknologi informasi berpengaruh signifikan terhadap ketepatwaktuan pelaporan keuangan.

Mengacu pada penelitian Trisaputra (2013) dan Chandra (2016) pemanfaatan teknologi informasi berpengaruh terhadap ketepatwaktuan pelaporan keuangan. Perbedaan ini dengan ini dengan penelitian sebelumnya adalah pada penambahan variabel yang mempengaruhi ketepatan waktu pelaporan keuangan yakni dengan menambah variabel sumber daya manusia (SDM). Menurut hasil penelitian Widyaningrum (2010) memperoleh hasil bahwa fungsi dan proses akuntansi yang telah dilaksanakan oleh pegawai yang memiliki pengetahuan dalam bidang akuntansi dapat membantu keandalan pelaporan keuangan pemerintah.

Dalam penyajian laporan keuangan, harus disadari bahwa banyak pihak yang akan mengandalkan ketepatwaktuan dalam laporan keuangan tersebut. Salah satu tujuannya adalah sebagai dasar dalam pengambilan keputusan. Oleh karena itu, informasi yang tersaji dalam laporan keuangan harus tepat waktu sehingga bermanfaat bagi para pemakai.

Suatu laporan keuangan bermanfaat apabila informasi yang disajikan dalam laporan keuangan dapat disajikan secara akurat dan tepat pada saat dibutuhkan oleh para pengguna informasi sebelum informasi tersebut kehilangan kesempatan untuk mempengaruhi keputusan ekonomi. Hal ini menunjukan bahwa ketepatwaktuan penyajian laporan keuangan sangat penting.

Meskipun sudah jelas bahwa adanya manfaat ketepatwaktuan pelaporan keuangan serta aturan-aturan yang mewajibkannya, namun masih terdapat faktor-faktor yang mempengaruhi sehingga terjadi keterlambatan dalam pelaporkan laporan keuangan. Dalam penelitian ini, peneliti hanya menguji beberapa faktor yang mempengarui, seperti: Pemanfaatan teknologi informasi serta SDM yang dimana terdapat pengaruh secara langsung terhadap ketepatwaktuan pelaporan keuangan.

Berdasarkan uraian diatas, adapun tujuan dari penelitian ini adalah sebagai berikut:

1. Untuk mengetahui pengaruh pemanfaatan teknologi informasi terhadap ketepatwaktuan pelaporan keuangan di Kabupaten Manokwari.

2. Untuk mengetahui pengaruh sumber daya manusia (SDM) terhadap ketepatwaktuan pelaporan keuangan di Kabupaten Manokwari.

\section{METODE PENELITIAN}

Tempat pelaksanaan penelitian dilaksanakan di Organisasi Perangkat Daerah Kabupaten Manokwari. Populasi adalah wilayah generalisasi yang terdiri atas obyek atau subyek yang memiliki kuantitas dan karakteristik tertentu yang ditetapkan oleh peneliti untuk dipelajari dan kemudian ditarik kesimpulannya (Sugiyono, 2015). Populasi dalam penelitian ini adalah pegawai dilingkungan Pemerintah Daerah Kabupaten Manokwari. Yang berjumlah 1.925 pegawai yang terbagi dalam 27 OPD antara lain: 1 Inspektorat, 2 Sekretariat, 1 Kantor, 7 Badan, dan 16 Dinas di Kabupaten Manokwari. Sampel adalah bagian dari jumlah dan karakteristik yang dimiliki oleh populasi (Sugiyono, 2015). Penyampelan atas responden dilakukan secara probability sampling yaitu pengambilan sampel yang memberikan peluang yang sama bagi setiap unsur populasi untuk dipilih menjadi unsur sampel. Teknik pengambilan sampel dengan menggunakan random sampling yang merupkan pengambilan sampel dari anggota populasi secara acak dan berstrata secara proposional. Di dalam penelitian ini, peneliti menggunakan jumlah sampel sebanyak 331 yang di peroleh dengan menggunakan rumus slovin.

Jenis data dalam penelitian ini adalah kuantitatif yaitu data yang berbentuk angka atau data yang diangkakan (Sugiyono, 2015). Jenis data penelitian ini adalah data primer yaitu data penelitian yang diperoleh atau dikumpulkan langsung dari sumber asli tanpa perantara. Sedangkan sumber data primer dalam penelitian ini diperoleh dari jawaban atas kuesioner yang dibagikan kepada responden yaitu Pegawai di OPD. 
Penelitian ini menggunakan teknik pengambilan data dengan menyebarkan kuesioner kepada responden. Kuesioner penelitian ini diserahkan langsung kepada responden atau meminta bantuan salah satu pegawai pada masing-masing OPD untuk mengkoordinir penyebaran dan pengumpulan kuesioner pada OPD tersebut. Kuesioner yang dibuat dengan menggunakan skala likert. Kuesioner tersebut diadopsi dari penelitian sebelumnya yaitu Safitri (2016).

Variabel terikat yang digunakan dalam penelitian ini adalah ketepatwaktuan pelaporan keuangan adalah tersedianya informasi bagi pembuat keputusan pada saat dibutuhkan sebelum informasi tersebut kehilangan kekuatan mempengaruhi keputusan (PP No.24 Tahun 2005). Indikator dalam ketepatanwaktu pelaporan keuangan adalah (1) Timeliness, (2) Sistematis Waktu, (3) Sistematis Unsur.

Pada penelitian ini yang menjadi variabel bebas adalah pemanfaatan teknologi informasi dan sumber daya manusia. Pemanfaatan Teknologi Informasi adalah perilaku sikap akuntan menggunakan teknologi informasi untuk menyelesaikan tugas dan meningkatkan kinerja. Teknologi informasi meliputi komputer dan jaringan. Komputer terdiri atas dua bagian besar yaitu perangkat lunak (software) dan perangkat keras (hardware). Jaringan merupakan suatu sistem yang menghubungkan komputer satu dengan yang lainnya sehingga dapat berinteraksi atau saling bertukar data, Indikator variabel Pemanfaatan Teknologi Informasi dilihat dari penggunaan komputer dan jaringan.

Kapasitas Sumber Daya Manusia adalah kemampuan sumber daya manusia untuk melaksanakan fungsi dan kewenangannya dalam organisasi dengan bekal pendidikan, pelatihan dan pengalaman yang memadai untuk mencapai tujuan organisasi secara efektif dan efisien. Indikator variabel Kapasitas Sumber Daya Manusia dilihat dari latar belakang pendidikan, pelatihan, pengalaman dan tanggungjawab.

Perkembangan teknologi informasi tidak hanya dimanfaatkan pada organisasi bisnis tetapi juga pada organisasi sektor publik, termasuk pemerintahan. Dalam penjelasan PP No. 56 Tahun 2005 tentang Sistem Informasi Keuangan Daerah disebutkan bahwa untuk menindaklanjuti proses pembangunan dengan prinsip tata kelola pemerintahan yang baik, pemerintah, dan pemerintah daerah berkewajiban untuk mengembangkan dan memanfaatkan kemajuan teknologi informasi untuk meningkatkan kemampuan mengelola keuangan daerah, dan menyalurkan informasi keuangan daerah kepada pelayanan publik.

Penelitian yang berhubungan dengan pemanfaatan sistem informasi dan teknologi informasi pada organisasi sektor publik sudah pernah dilakukan. Uraian dan temuan empiris mengenai teknologi informasi menunjukkan bahwa pengolahan data dengan memanfaatkan teknologi informasi (komputer dan jaringan) akan memberikan banyak keunggulan baik dari sisi keakuratan/ketepatan hasil operasi maupun predikatnya sebagai mesin multiguna. Pemanfaatan teknologi informasi juga akan mengurangi kesalahan yang terjadi (Nurillah, 2014). Berdasarkan uraian diatas, penelitian ini dimaksudkan untuk menguji kembali hubungan antara teknologi informasi dengan ketepatwaktuan pelaporan keuangan.
$\mathrm{H}_{1}$ : Pemanfaatan Teknologi Informasi berpengaruh terhadap Ketepatwaktuan Pelaporan Keuangan.

SDM merupakan pengetahuan, keterampilan, dan kemampuan seseorang yang dapat digunakan untuk menghasilkan layanan profesional. Karyawan dengan SDM tinggi lebih memungkinkan untuk memberikan layanan yang konsisten dan berkompetensi tinggi. Untuk menilai kapasitas dan kualitas SDM dalam melaksanakan suatu fungsi, termasuk akuntansi, dapat dilihat dari kompetensi sumber daya tersebut.

Penelitian yang dilakukan oleh Widyaningrum (2010) memperoleh hasil bahwa fungsi dan proses akuntansi telah dilaksanakan oleh pegawai yang memiliki pengetahuan dalam bidang akuntansi sehingga dapat membantu keandalan pelaporan keuangan pemerintah.

Yunina (2016) memberi keyakinan memadai mengenai pencapaian tujuan pemerintah daerah karena kapasitas sumber daya manusia yang terdapat pada masing-masing SKPK yang ada di Kabupaten Pidie Jaya telah mendukung baik dari segi kualitas maupun kuantitas, sehingga penyajian laporan keuangan dapat dilaporkan tepat waktu. Berdasarkan uraian diatas, penelitian ini dimaksudkan untuk menguji kembali hubungan antara sumber daya 
manusia dengan ketepatwaktuan laporan keuangan.

$\mathrm{H}_{2}$ : Sumber Daya Manusia berpengaruh terhadap Ketepatwaktuan Pelaporan Keuangan.

Uji validitas yang dilakukan menggunakan teknik analisis bivariate correlation dengan syarat yang digunakan untuk menyatakan item pernyataan valid. Yaitu apabila nilai signifikansinya $<0,05$. Untuk mengukur reliabilitas dugunakan uji statistik Cronbach Alpha $(\alpha)$ dengan syarat untuk menyatakan variabel handal yaitu nilai Cronbach Alpha $>0,60$.

Pengujian asumsi klasik yang digunakan adalah Uji multikolinearitas, uji heteroskedastisitas, dan uji normalitas. Uji asumsi klasik dalam penelitian ini, dilakukan agar model-model regresi signifikan dan represantif. Untuk menguji apakah data residual berdistribusi normal atau tidak yaitu dengan uji statistic Kolmogorov-Smirnov Test. Residual terdistribusi normal jika memiliki nilai signifikan $>0,05$.

Multikolinieritas dapat dilihat dari nilai tolerance dan lawannya, variance inflation factor (VIF). Kedua ukuran menunjukan setiap variabel bebas manakah yang dijelaskan oleh variabel bebas lainnya, nilai tolerance yang rendah sama dengan nilai VIF tinggi (karena $\mathrm{VIF}=1 /$ Tolerance $)$. Jika nilai $\mathrm{VIF}<10$ dan tolerance $>0,1$ menunjukan tidak terdapat multikolinieritas dalam penelitian tersebut.

Model regresi yang baik adalah yang homoskedastisitas atau tidak terjadi heteroskedastisitas (Ghozali, 2006). Untuk mengetahui adanya heteroskedastisitas dapat menggunakan uji Glejser. Dalam uji ini, apabila hasilnya signifikan $>0,05$.

Analisis regresi berganda (multiple regression) dilakukan untuk menguji pengaruh dua atau lebih variabel independen (explanatory) terhadap satu variabel dependen (Ghozali, 2006). Model regresi berganda dalam pernyataan ini dinyatakan sebagai berikut:

$$
Y=\alpha+\beta_{1} X_{1}+\beta_{2} X_{2}+e
$$

Keterangan:

$\mathrm{Y}=$ Ketepatwaktuan Pelaporan Keuangan

$\alpha=$ Konstanta

$$
\begin{aligned}
\beta_{1} & =\text { Koefisien Regresi Pemanfaatan } \\
& \text { Teknologi Informasi } \\
\beta_{2}= & \text { Koefisien Regresi Sumber Daya } \\
& \text { Manusia } \\
\mathrm{X}_{1}= & \begin{array}{l}
\text { Variabel Pemanfaatan Teknologi } \\
\text { Informasi }
\end{array} \\
\mathrm{X}_{2}= & \text { Variabel Sumber Daya Manusia } \\
e & =\text { Eror }
\end{aligned}
$$

\section{HASIL DAN PEMBAHASAN}

Dalam penelitian ini, peneliti menguji tentang Pengaruh Pemanfaatan Teknologi Informasi dan Sumber Daya Manusia terhadap Ketepatwaktuan Pelaporan Keuangan Pemerintah Daerah di Organisasi Perangkat Daerah Kabupaten Manokwari yang terdiri dari 1 Inspektorat, 2 Sekretariat, 1 Kantor, 7 Badan, dan 16 Dinas.

Data dalam penelitian ini diperoleh dengan cara menyebarkan kuesioner sebanyak 331 kuesioner yang diantar langsung ke 27 Organisasi Perangkat Daerah Kabupaten Manokwari dengan responden sebanyak 331. Kuesioner yang kembali kepada peneliti sebanyak 114 lembar kuesioner karena pada saat penyebaran kuesioner dinas terkait yang menjadi objek penelitian sebagian menolak untuk dijadikan responden.

Pada uji validitas menunjukan bahwa semua item pertanyaan pada setiap variabel penelitian adalah valid atau dapat dikatakan sah sebab tingkat signifikasinya $<0,05$. Sedangkan uji reliabilitas menunjukkan bahwa Cronbrach's alpha $>0,60$. Maka dapat disimpulkan bahwa seluruh item pertanyaan dalam kuesioner untuk setiap variabel dalam penelitian ini danyatakan handal (reliabel).

Uji statistik Kolmogorov-Smirnov Test digunakan untuk menguji normalitas. Residual terdistribusi normal jika memiliki nilai signifikan $>0,05$.

Tabel 1 menunjukan bahwa nilai KolmogorovSmirnov adalah 1,121 pada signifikansi 0,162 lebih besar dari 0,05 , sehingga dapat disimpulkan bahwa data berdistribusi normal.

Tabel 2 menunjukan bahwa variabel independen memiliki nilai VIF dibawah 10 dan nilai tolerance diatas 0,10 maka dapat disimpulkan bahwa tidak terdapat multikolonieritas anatar variabel independen dalam model regresi. 
Tabel 1. Uji Normalitas

\begin{tabular}{|c|c|c|}
\hline \multicolumn{3}{|c|}{ One-Sample Kolmogorov-Smirnov Test } \\
\hline & & idual \\
\hline $\mathrm{N}$ & & 114 \\
\hline \multirow{2}{*}{ Normal Parameters $^{a}$} & Mean & 0000000 \\
\hline & Std. Deviation & 3,57496405 \\
\hline \multirow[t]{3}{*}{ Most Extreme Differences } & Absolute &, 105 \\
\hline & Positive &, 105 \\
\hline & Negative &,- 089 \\
\hline Kolmogorov-Smirnov $Z$ & & 1,121 \\
\hline Asymp. Sig. (2-tailed) & &, 162 \\
\hline
\end{tabular}

Tabel 2. Uji Multikolonieritas

\begin{tabular}{ccc}
\hline \multirow{2}{*}{ Model } & \multicolumn{3}{c}{ Coleniarity Statistic } \\
\cline { 2 - 3 } & Tolerance & VIF \\
\hline PTI & 0,580 & 1,723 \\
\hline SDM & 0,580 & 1,723 \\
\hline
\end{tabular}

Tabel 3. Uji Heteroskedastisitas

\begin{tabular}{lcc}
\hline \multicolumn{1}{c}{ Variabel } & Signifikansi & Keterangan \\
\hline Pemanfaatan Teknologi Informasi $\left(\mathrm{X}_{1}\right)$ & 0,520 & Homokedastisitas \\
\hline Sumber Daya Manusia $\left(\mathrm{X}_{2}\right)$ & 0,525 & Homokedastisitas \\
\hline
\end{tabular}

Tabel 4. Uji Regresi Berganda

\begin{tabular}{|c|c|c|c|c|}
\hline \multirow{2}{*}{\multicolumn{2}{|c|}{ Model }} & \multicolumn{2}{|c|}{ Unstandardized coefficients } & \multirow{2}{*}{$\begin{array}{c}\text { Standardized coefficients } \\
\text { Beta }\end{array}$} \\
\hline & & $B$ & Std. Error & \\
\hline \multirow{3}{*}{1} & (Constant) & 10.350 & 2.906 & \\
\hline & PTI & .518 & .107 & .453 \\
\hline & SDM & .260 & .091 & 268 \\
\hline
\end{tabular}

Dari Tabel 3 dapat dilihat bahwa nilai signifikansi pemanfaatan teknologi informasi sebesar 0,520, nilai signifikansi sumber daya manusia sebesar 0,525. Hal ini menunjukan nilai signifikansi lebih besar dari 0,05 maka dapat disimpulkan bahwa tidak terjadi heterokedastisitas.

Selanjutnya, analisis regresi berganda (multiple regression) dilakukan untuk menguji pengaruh dua atau lebih variabel independen (explanatory) terhadap satu variabel dependen (Ghozali, 2006). Dari tabel 4 diperoleh persamaan regresi sebagai berikut:

$$
Y=10,350+0,518 X 1+0,260 X 2+e
$$

Bentuk persamaan diatas memberikan gambaran bahwa:

1. Konstanta sebesar 10,350 menyatakan bahwa variabel bebas dianggap konstans, maka faktor-faktor yang mempengaruhi ketepatwaktuan pelaporan keuangan adalah sebesar 10,350 .

2. Pemanfaatan teknologi informasi (X1) mempunyai nilai koefisien sebesar 0,518 dan bernilai positif, yang berarti apabila terjadi peningkatan terhadap variabel
Pemanfaatan teknologi informasi maka ketepatwaktuan pelaporan keuangan akan bertambah sebesar 0,518 .

3. Sumber daya manusia (X2) mempunyai nilai koefisien sebesar 0,260 dan bernilai positif, yang berarti apabila terjadi peningkatan terhadap variabel Pemanfaatan teknologi informasi maka ketepatwaktuan pelaporan keuangan akan bertambah sebesar 0,260.

Berdasarkan tabel 5 diatas dapat diketahui $F_{\text {hitung }}$ yaitu sebesar 42,722 dengan probabilitas signifikansi sebesar 0,000 karena probabillitas jauh lebih kecil dari 0,05 sehingga dapat disimpulkan secara simultan variabel pemanfaatan teknologi informasi dan sumber daya manusia berpengaruh terhadap ketepatwaktuan pelaporan keuangan.

Uji t pada dasarnya menunjukan seberapa jauh pengaruh satu variabel bebas secara individual dalam menerangkan variasi variabel terikat (Ghozali, 2006). Pengujian dilakukan dengan menggunakan signifikan level $0,05(\alpha=5 \%)$. Jika nilai $\mathrm{t}>0,05$ maka hipotesis ditolak. Ini berarti bahwa secara parsial variabel bebas tersebut tidak mempunyai pengaruh yang 
signifikan terhadap variabel terikat, sebaliknya jika nilai $\mathrm{t} \leq 0,05$ maka hipotesis diterima. Ini berarti secara parsial variabel bebas tersebut mempunyai pengaruh yang signifikan terhadap variabel terikat.

Tabel 5. Uji $F$

\begin{tabular}{|c|c|c|c|c|c|c|}
\hline \multicolumn{7}{|c|}{$A N O V A^{b}$} \\
\hline Model & Sum of Squares & $d f$ & Mean Square & $F$ & & Sig. \\
\hline Regression & 1111,678 & 2 & 555,839 & 42,722 &, $000^{\mathrm{a}}$ & \\
\hline Residual & 1444,182 & 111 & 13,011 & & & \\
\hline Total & 2555,860 & 113 & & & & \\
\hline
\end{tabular}

Tabel 6. Uji $t$

\begin{tabular}{ccc}
\hline Model & $t$ & Sig. \\
\hline PTI & 4,841 & 0,000 \\
\hline SDM & 2,862 & 0,005 \\
\hline Berdasarkati
\end{tabular}

Berdasarkan Tabel 6, hasil pengujian hipotesis secara parsial untuk setiap variabel independen adalah sebagai berikut:

1. Variabel Pemanfaatan Teknologi Informasi memiliki nilai Thitung sebesar 4,841 dengan nilai signifikansi sebesar 0,000 . Oleh karena nilai signifikansi lebih kecil dari 0,005 maka $\mathrm{H}_{0}$ di tolak dan $\mathrm{H}_{1}$ diterima, sehingga dapat disimpulkan bahwa Pemanfaatan Teknologi Informasi berpengaruh terhadap Ketepatwaktuan Pelaporan Keuangan.

2. Variabel Sumber Daya Manusia memiliki nilai Thitung sebesar 2,862 dengan nilai signifikansi sebesar 0,005. Oleh karena nilai sigifikansi lebih kecil dari 0,005 maka $\mathrm{H}_{2}$ diterima, sehingga dapat disimpulkan bahwa variabel Sumber Daya Manusia berpengaruh terhadap Ketepatwaktuan Pelaporan Keuangan.

Koefisien determinasi bertujuan mengukur seberapa besar kemampuan variabel bebas dalam menjelaskan variabel terikatnya. Nilai koefisien determinasi adalah antara 0 (nol) dan 1 (satu). Semakin tinggi nilai koefisien determinasi $\left(R^{2}\right)$ berarti semakin tinggi kemampuan variabel independen dalam menjelaskan variasi perubahan terhadap variabel dependent (Ghozali, 2006).

Tabel 7. Uji Koefisien Determinasi $\left(\mathrm{R}^{2}\right)$

\begin{tabular}{|c|c|c|c|c|}
\hline \multicolumn{5}{|c|}{ Model Summary ${ }^{b}$} \\
\hline Model & $R$ & $R$ Square & Adjusted R Square & Std. Error of the Estimate \\
\hline 1 &, $660^{\mathrm{a}}$ & 435 &, 425 & 3,607 \\
\hline
\end{tabular}

Tabel 7 menunjukan bahwa Adjusted $R$ Square sebesar 0,425 artinya sebesar $42,5 \%$ variabel dependen yaitu ketepatwaktuan pelaporan keuangan dapat dijelaskan oleh variabel independen yaitu pemanfaatan teknologi informasi dan sumber daya manusia. Sedangkan sisanya sebesar $57,5 \%$ dijelaskan oleh variabel lain di luar penelitian ini.

\section{Hubungan Pemanfaatan Teknologi Informasi dan Ketepatwaktuan Pelaporan Keuangan}

Berdasarkan hasil pengujian hipotesis secara parsial (uji t) variabel Pemanfaatan Teknologi Informasi mempunyai nilai signifikansi lebih kecil dari alpha $5 \%(0,000<0,005)$ sehingga dapat disimpulkan bahwa variabel Pemanfaatan Teknologi Informasi berpengaruh terhadap Ketepatwaktuan Pelaporan Keuangan.
Hal ini sejalan dengan penelitian yang dilakukan oleh Trisaputra (2013) dan Chandra (2016) yang menyatakan Pemanfaatan Teknologi Informasi berpengaruh positif terhadap Ketepatwkatuan Pelaporan Keuangan, Widyaningrum (2010) menyatakan bahwa pemanfaatan teknologi berpengaruh positif signifikan terhadap ketetpatwaktuan pelaporan keuangan pemerintah daerah, Wiwik (2010) menyatakan bahwa pemanfaatan teknologi informasi berpengaruh positif terhadap keterandalan dan ketetpatwaktuan pelaporan keuangan pemerintah daerah, Yunina (2016) menyatakan bahwa pemanfaatan teknologi informasi dan ketepatwaktuan pelaporan keuangan pemerintah menunjukan hasil signifikansi positif, dan Safitri (2016) juga menyatakan bahwa kualitas pemanfaatan teknologi informasi berpengaruh positif 
terhadap keandalan dan ketepatwaktuan pelaporan keuangan pemerintah daerah.

Dapat dikatakan pemanfaatan teknologi informasi OPD Kabupaten Manokwari dikategorikan baik dan berpengaruh terhadap ketepatwaktuan pelaporan keuangan. Hasil penelitian ini menyimpulkan bahwa semakin baik pemanfaatan teknologi informasi dalam suatu OPD akan meningkatkan ketepatwaktuan pelaporan keuangan pemerintah menjadi baik.

\section{Hubungan Sumber Daya Manusia dan Ketepatwaktuan Pelaporan Keuangan}

Berdasarkan hasil pengujian hipotesis secara parsial (uji t) vaariabel Sumber Daya Manusia mempunyai nilai signifikansi lebih kecil dari alpha $5 \% \quad(0,005<0,005) \quad$ sehingga dapat disimpulkan bahwa variabel Sumber Daya Manusia berpengaruh terhadap Ketepatwaktuan Pelaporan Keuangan. Hal ini sejalan dengan penelitian yang dilakukan oleh Wiwik (2010) menyatakan bahwa SDM, berpengaruh positif terhadap keterandalan dan ketetpatwaktuan pelaporan keuangan pemerintah daerah, Yunina (2016) menyatakan bahwa kapasitas sumber daya manusia dan ketepatwaktuan pelaporan keuangan menunjukan hasil signifikansi positif, dan Safiti (2016) menyatakan bahwa SDM berpengaruh positif terhadap keandalan dan ketepatwaktuan pelaporan keuangan pemerintah daerah.

Dapat dikatakan Sumber Daya Manusia pada OPD Kabupaten Manokwari dikategorikan baik dan berpengaruh terhadap ketepatwaktuan pelaporan keuangan. Hasil penelitian ini menyimpulkan bahwa semakin baik sumber daya manusia dalam suatu OPD akan meningkatkan ketepatwaktuan pelaporan keuangan pemerintah menjadi baik.

\section{KESIMPULAN}

Berdasarkan hasil analisis dan penelitian dapat dikemukakan kesimpulan sebagai berikut:

1. Penelitian ini membuktikan bahwa Pemanfaatan Teknologi Informasi berpengaruh signifikan terhadap ketepatwaktuan pelaporan keuangan pada OPD Kabupaten Manokwari. Dimana semakin baik pemanfaatan teknologi informasi maka semakin baik pula ketepatwaktuan pelaporan keuangan pemerintah Daerah.
2. Penelitian ini membuktikan bahwa Sumber Daya Manusia berpengaruh signifikan terhadap ketepatwaktuan pelaporan keuangan pada OPD Kabupaten Manokwari. Dimana semakin baik sumber daya manusia maka semakin baik pula ketepatwaktuan pelaporan keuangan pemerintah Daerah.

Berdasarkan hasil penelitian yang telah dilakukan, ada beberapa saran yang dapat dipertimbangkan oleh berbagai pihak:

1. Sebaiknya instansi pada pemerintah daerah dapat bekerja dengan efektif dan efisien sehingga laporan keuangan dapat disajikan dengan tepat waktu. Hal ini juga merupakan langkah pemerintah daerah untuk menghindari keterlambatan penyampaian laporan keuangan.

2. Diharapkan Pemerintah Daerah agar lebih memanfaatkan jaringan internet sebagai penghubung unit kerja dalam pengiriman data dan informasi agar laporan keuangan dapat disajikan secara tepat waktu. Hal tersebut dapat dilihat dari data responden bahwa beberapa instansi masih belum memiliki dan belum memanfaatkan jaringan internet di unit kerja.

3. Sebaiknya aparatur-aparatur yang berada dan bekerja di seluruh instansi pemerintah daerah harus sesuai dalam bidang pekerjaan yang digeluti dengan ilmu pengetahuan yang dimiliki. Hal ini diharapkan agar hasil yang diperoleh dapat lebih baik sehingga mengurangi kesalahan dan kecurangan. Hal tersebut dapat dilihat dari data responden yang membuktikan bahwa subbagian keuangan/akuntansi memiliki jumlah staf yang belum cukup.

Adapun keterbatasan dalam penelitian ini adalah seluruh kantor yang menjadi tempat penelitian tidak berada dalam satu kawasan, sehingga dapat membutuhkan waktu yang lebih lama untuk mengantar dan mengambil kembali hasil penelitian.

\section{DAFTAR PUSTAKA}

Arfianti, Dita. (2011). Analisis Faktor-Faktor Yang Mempengaruhi Nilai Informasi Pelaporan Keuangan Pemerintah Daerah (Studi Pada Satuan Kerja Perangkat Kerja Daerah di Kabupaten 
Batang). Skripsi. Fakultas Ekonomi. Universitas Diponegoro.

Chandra, P.; I., Momuat. (2016). Pengaruh Pemanfaatan Teknologi Informasi terhadap Ketepatan Waktu Pelaporan Keuangan dalam Rangka Mewujudkan Transparasi dan Akuntabilitas (Studi Pada Kabupaten Minahasa Tenggara). Fakultas Ekonomi Bisnis. Universitas Sam Ratulangi, Manado.

Ghozali, Imam. (2006). Aplikasi Analisis Multivariate Dengan Program SPSS. Semarang; Badan Penerbit Universitas Diponegoro.

Hartono, Jogiyanto. (1995). Analisis dan Desain Sistem Informasi. Penerbit Andi. Yogyakarta.

Mardiasmo. (2002). Akuntansi Sektor Publik Edisi Pertama. Penerbit Andi. Yogyakarta.

Nurillah, As, Syifa. (2014). Pengaruh Kompetensi Sumber Daya Manusia, Penerapan Sistem Akuntansi Keuangan Daerah (SKAD), Pemanfaatan Teknologi Informasi dan Sistem Pengendalian Intern terhadap Kualitas Laporan Keuangan Pemerintah (Studi Empiris Pada SKPD Kota Depok). Fakultas Ekonomika dan Bisnis. Universitas Diponegoro.

Peraturan Pemerintah Nomor 71 Tahun (2010). tentang Standar Akuntansi Pemerintahan Berbasis Akrual. Jakarta.

Peraturan Pemerintah Nomor 24 Tahun (2005). tentang Standar Akuntansi Pemerintahan. Jakarta.

Peraturan Pemerintah Nomor 56 Tahun (2005). tentang Sistem Informasi Keuangan Daerah. Jakarta.

Respati, Novita Weningtyas. (2001). FaktorFaktor yang Berpengaruh terhadap Ketepatan Waktu Pelaporan Keuangan:
Studi Empirirs di Bursa Efek Jakarta. Jurnal Maksi. Vol. 4. No. 3.

Safitri, Hudalilah. (2016). Pengaruh Sumber Daya Manusia dan Teknologi Informasi terhadap Keandalan dan Ketepatwaktuan Pelaporan Keuangan Pemerintah Daerah (Studi Pada Satuan Kerja Perangkat Daerah Kabupaten Lumajang).

Sugiyono. (2015). Metode Penelitian Kuantitatif Kualitatif dan $R \quad \& \quad D$. Bandung: Alfabeta.

Trisaputra, Andry. (2013). Pengaruh Pemanfaatan Teknologi Informasi dan Pengawasan Keuangan Daerah terhadap Ketepatan Waktu Pelaporan Keuangan Pemerintah Daerah (Studi Empiris Pada SKPD Pemerintah Provinsi Sumatra Barat). Skripsi. Fakultas Ekonomi dan Bisnis. Universitas Negeri Padang.

Undang-Undang Nomor 17 Tahun 2003 tentang Keuangan Negara. Jakarta: 2003.

Undang-Undang Nomor 32 Tahun 2004 tentang Pemerintah Daerah. Jakarta: 2004.

Widjajanto, Nugroho. (2001). Sistem Informasi Akuntansi. Jakarta: Erlangga.

Widyaningrum, Celviana Rahmawati. (2010). Pengaruh Sumber Daya Manusia dan Pemanfaatan Teknologi Informasi terhadap Keterandalan dan Ketepatanwaktu Pelaporan Keuangan Pemerintah Daerah dengan Variabel Intervening Pengendalian Intern Akuntansi. Symposium Nasional Akuntansi XIII. Purwokerto.

Yunina. (2016). Pengaruh Kapasitas Sumber Daya Manusia, Pengendalian Intern Akuntansi dan Pemanfaatan Teknologi Informasi terhadap Ketepatan Waktu Pelaporan Keuangan Pemerintah Kabupaten Pidie Jaya 